\title{
THE GREEK MONASTERIES IN SOUTH
}

\section{ITALY. II.}

\section{THE DEVELOPMENT OF SCRIPTORIA.}

THE development of scriptoria and the growth of the literary instinct is gradual, and is chiefly to be traced in the life of Nilus.

The life of Elias Junior not merely gives no sign of any literary taste on the part of the saint, but affords positive evidence that he regarded it as a sinful tendency. On one occasion he and Daniel were making an expedition from Salinae to Pentadattilo ${ }^{1}$, and while they were crossing the marshy ground (now drained) known as Il Lacco, Daniel produced a beautiful copy of the Psalter, which he had written himself. 'I vero,' said Elias ${ }^{2}$, 'atque illud in stagnum projice.' Daniel did so, knowing, says the writer, the meaning of obedience. After they had gone six miles, Elias sent Daniel back to look for the Psalter, and it was recovered unhurt. 'Tua,' said Elias, 'obedientia, fili, codicem servavit incolumem. Verumtamen operae pretium est, paupertatem summo nos studio complecti ; ne forte rideant nos caelestes illae mentes, qui mundo scilicet remisisse ac monasticum institutum sequi profitcantur. Sicuti enim quis valere minime dicendus est, qui vel uno corporis membro laboret, ita nec monachum vere inopem, et ab aegritudinibus animi immunem, qui aliquo uno caducarum rerum desiderio teneatur.'

Elias's sentiment is excellent from the perverted point of view of an illiterate monk, but it shows clearly that the scriptorium in any monastery with which he had to deal would be small and insignificant.

Elias Spelaeotes was more literary than his namesake. He was not, so far as his life tells us, especially famous in this direction, but he appears to have spent some portion of each day, while

1 See p. $5^{28}$, inf. 2 A. SS. Aug. iii p 497 a (should be D). 
he was at Patras ${ }^{1}$, in writing. It would also seem that he had some knowledge of theology and philosophy, since he educated Lucas not merely to a knowledge of the scriptures, but also ${ }^{2}$ of 'profunda mysteria ac philosophorum subtilitates et latibula.'

Cod. Evg. 60 bears the name of an Elias Spelaeotes. But it is dated 1021 , was written in Castro de Colonia, and is not, I think, a South Italian MS. It is perhaps evidence, though slender, for thinking that Elias did write a manuscript, for the name may have been copied from an older MS. It is very common for scribes to copy colophons without acknowledgement.

Beyond the passage already quoted there is no evidence that Lucas was literary or that he was famous as a scribe, and I do not think that it really means more than that he was eloquent in discourse about philosophy and theology. Vitalis, too, admitted and perhaps regretted his ignorance, 'parum quasdam litteras novi' said he to the catapan of Bari ${ }^{3}$.

Nilus, on the other hand, was extremely literary, and probably founded a distinct school of calligraphy, for there are many references in his life to the systematic production of MSS, and to his interest in literary and intellectual pursuits.

From his youth up he seems to have been fond of learning. He was familiar 4 , we are told, with the lives of the great saints, such as Antony, Saba, or Hilarion, and he used to read them with great eagerness and care. It was this knowledge, and the skill which he seems to have possessed in expounding it, which made him famous when he was on Mount Mercury.

Frequently, we are told ${ }^{5}$, the brethren in the monastery of Fantinus, in which Nilus was, used to come and ask him to expound the meaning of the scriptures; and, hearing the words of grace which fell from the mouth of Nilus, and admiring the resplendent virtue of Fantinus, they looked on them as a new Peter and Paul. And a little further on we find that he had a dispute with John, the Abbot of another little monastery on Mount Mercury, perhaps that which was afterwards known as Giovanni de Lauro, as to the interpretation of a passage in Gregory Nazianzen; the old man silenced him by accusing him of youth and inexperience ${ }^{6}$, a reproof which Nilus accepted
1 A.SS. Sept. iii p. $858 \mathrm{D}$.
${ }^{2} A$.SS. Oct. vi p. $33^{8}$ F.
3 A.SS. Mart. ii p. *29 $\mathrm{B}$.
'P. G. 120, p. 20 A.
S P. G. 120 , p. 33 C.
- P. G. 120, p. $3^{6} \mathrm{D}$. 
in all humility in spite of the efforts made by the devil, who appeared in the specious guise of SS. Peter and Paul to suggest passages which might bear on the point at issue; but the next day, touched by the gentleness of Nilus, John admitted that he had only been testing the young man's character, and that the latter's interpretation was really right.

When he was at S. Adrian's his reputation was so great that several Greek officials went out to interview him ${ }^{1}$, more it would seem from curiosity than from any higher motive. The scene is worth reproducing, for it shows the great power of Nilus and his appreciation of the ethical character of Christianity.

'There will be but few saved,' he had warned his hearers. 'Ah,' they in effect replied, ' this cannot affect us; we have the sacraments; we adore the cross; we are members of the Church.' 'Take it as a certain fact,' said Nilus, 'that unless you lead virtuous lives, and love virtue, not one of you will escape damnation, in spite of the things on which you rely.' His hearers returned to the argument, 'We are told that even a cup of cold water given in charity has its reward.' 'This,' said Nilus, 'was said to those who had no possessions; but what will happen to you, who are rich, and yet take away from the poor even the cold water which he has?' The visitors thought it better to change the subject, and asked whether Solomon had been saved, and what was the fruit which Adam ate in Eden.

The first inquiry Nilus answered by saying that the more important question for the inquirer concerned his own salvation; and when in reply to the second some one suggested that the forbidden fruit was a wild apple, and was laughed at by the others, he settled the point summarily by saying, 'Do not laugh: the reply was as sensible as the inquiry!'

And in the same spirit, so far superior to the usual ecclesiastical logic and perverted reasoning of the period, he dealt with all his sensation-seeking questioners.

Did Nilus write any original works? There are none mentioned in the Patrologia Graeca, but there are in Cod. Crypt. $\Delta . \gamma \cdot \mathbf{x x i}^{2}$ two poems attributed to him: (I) concerning S. Benedict of Monte Cassino, (2) concerning Nilus of Sinai. This is a paper MS of the eighteenth century. Its evidence is alone scarcely
${ }^{1}$ P. G. I20, p. $88 \mathrm{f}$.
2 Codices Cryptenses, by Dom Rocchi, ad loc. 
sufficient; the internal evidence of the hymns would be valuable, but they are not published, and the matter must be left undecided.

That Nilus was a great scribe is as certain as that he was no mean theologian and student of literature. Almost the first thing that we are told of his career, after his admission to the monastic order at S. Nazarius, is that he spent the greater part of each day in writing ${ }^{1}$, in order to leave a record of the work of his hands and to avoid the charge of not working for his maintenance. Nor was this a merely complimentary payment : that his calligraphy had a real and marketable value is shown by an interesting episode in his life on Mount Mercury ${ }^{2}$. He had received a monk into his monastery, who had with him three pieces of money. Nilus made him give these to the poor, and taught him the 'difficult art' of calligraphy. But after a time the discipline of monastic life became irksome to him, and wishing to go away, he asked for the return of his money. 'Very well,' said Nilus, ' if you will write a transference to me for the reward which would have been yours in the kingdom of heaven, I will pay you back your three pieces of money.'

The monk, curious to see how the penniless saint would fulfil his promise, wrote a transference as he was directed and placed it on the altar. Nilus went to a neighbouring monastery, perhaps at Seminara, and borrowed three pieces of money, which he gave to the monk, who, as the story adds in a naive parenthesis, soon died. Then he set to work to write three Psalters, finishing them in four days each, in order to satisfy the debt which he had incurred at 'the command of Christ.'

In this case he had a definite object in writing, but it would seem as though the making of manuscripts was always a part of his daily routine. From the break of day until terce he used to write 'swiftly and elegantly,' filling four sheets a day with his small and compact writing. How much does this mean ? Obviously it depends on the size of his sheets, which, it may be mentioned, we find Stephen going to buy at Rossano; but if we take the two MSS which seem to be most probably written by the hand of Nilus (Crypt. B a xix ${ }^{3}$ and Crypt. $\mathrm{B}$ a xx), we find

1 Sirletto's Latin. v. P. G I 20, p. 3 I c. 2P. G. I 20, p. 49 B.

3 Codices Cryptenses, ad loc. Possibly these MSS have both been cut down, as they were probably once bound together, but they must have been of nearly equal size. 
that both are $25 \times 19 \mathrm{~cm}$., a medium size, of which a skilful scribe might well fill a quaternion in three hours, though I do not think that many men could do so.

The handwriting of Nilus and his school is a somewhat important subject in Greek palaeography, and not quite a simple one. A considerable amount of research in Italy will have to be accomplished before it is possible to treat it in a really satisfactory manner; but it is already possible to indicate several well-established points, to show what are the problems which must be solved, and to suggest tentatively the results which may be looked for.

i. The evidence for attributing Cod. Crypt. $\mathrm{B}$ a xix, $\mathbf{x x}$ to Nilus is in each case good, but requires further investigation.

(I) Cod. $\mathrm{B}$ a xx ${ }^{1}$ contains on $\mathrm{f} .59$ verso the subscription $\tau \hat{\varphi}$

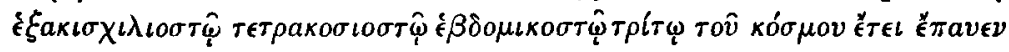

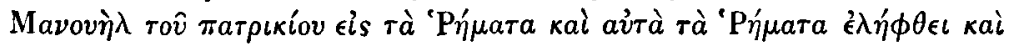

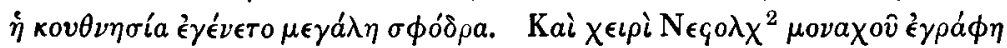

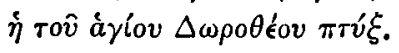

I do not know where Rhemata was, but it seems clear that a place of some kind is intended. I suppose it was in Sicily, as Manuel's expedition was directed against that country. Dom

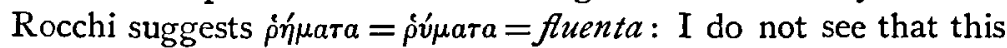
is any easier to understand, and more probably it is Rometta ${ }^{3}$ near Messina. This subscription seems decisive in favour of Nilus's authorship, unless it be suggested that it was written by another Nilus; but it must be noticed that Dom Rocchi says on f. $62 v$. ' Versus cum acrostichide alphabetaria scripsit Paulus monachus

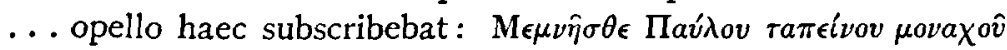

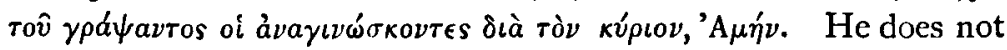
say whether this acrostic and the subscription are in the same hand as the rest of the manuscript or not. As he regards the manuscript as the work of Nilus, there can be little doubt that it is not.

(2) The case of Cod. B a xix is similar. At the end of the treatise of Diadochus (f. 83 ) there are the following verses ${ }^{4}$ :-

1 Codices Cryptenses, ad loc.

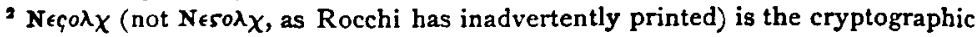
mode of writing Neiliov, according to the usual method.

${ }^{3}$ Sometimes spelt Rametta.

- Codices Cryptenses, ad loc. 


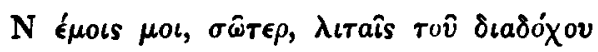

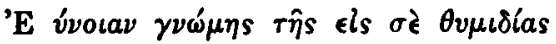

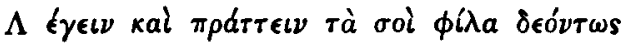

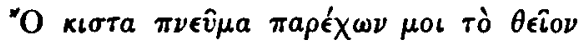

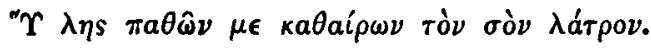

These form a single acrostic, of which the initial letters give the word $\mathbf{N} \in \lambda o v$, and this is probably meant as an indication of the name of the scribe.

It is curious and important that here also there are some extracts from Basil in the hand of Paul, the first abbot of Grotta Ferrata, who wrote Cod. B a i, the celebrated Isidore MS, at the command of Nilus in 986 ; but Rocchi thinks it is not the same hand as that which wrote the note in Cod. B a xx.

These two MSS, $\mathrm{B}$ a xix, and $\mathrm{B}$ a xx, were once bound up in one volume together with $\mathrm{B}$ a $\mathbf{x x i}$, which is also probably in the hand of Nilus, but has no subscription. They were divided and bound separately by Dom Jos. Cozza ${ }^{1}$.

There is no good reason therefore for doubting that these MSS were written by Nilus of Rossano; the name, the beauty of the writing, the date, and the connexion with Paul of Grotta Ferrata all point to the same conclusion. The only point which is at all adverse is the mention of Rometta (if, indeed, $\dot{\rho}^{\prime} \mu a r a$ is Rometta). Batiffol seems to think that this implies that the MS was written at Rometta, but it is quite unnecessary to suppose that a MS which records the capture of a town in a given year was written in it. On the contrary, it is extremely probable that it was written at a safe distance outside of it.

ii. The palaeographical characteristics of these MSS are very marked, as compared with Greek MSS of the same date from the Levant. The vellum on which they are written is much inferior, it is not so smooth and it is not so white, and though the writing is compact and beautiful, it has a distinct individuality, and perhaps a certain stiffness which is easy to recognize, though it is almost impossible to describe; but the most characteristic point is the colouring and ornamentation. A constant feature is a kind of plait of different colours (but never, I think, gold), with tags at the corners, which is placed at the beginning of a book.

1 Codices Cryptenses, p. 100. 
Initial letters are filled up with a wash of tran-parent ink ${ }^{1}$ (generally yellow), and marginal notes and titles are usually covered in a similar way, by a wash of yellow ink. I do not think that this is ever found in Greek MSS written in the East.

A full description of these palaeographical details is given in Mgr. Batiffol's L'Abbaye de Rossano, p. 89, though he is actually describing other MSS. His views on the subject demand attention, although I think that he has missed the true significance of some of the facts which he gives. He has collected all the dated MSS of the same kind as that described, and formed from their evidence the theory that the origin of this school of calligraphy is to be found in the neighbourhood of Capua, and traced to the influence of the Lombardic type of Latin MSS such as are found at Monte Cassino. This theory is probably true, but it is not the whole truth. So far as the connexion with Lombardic MSS is concerned it may be taken as certain; no one can compare a Lombardic MS, an ordinary Greek MS, and one of the Nilus MSS, without seeing that the last has many points of peculiarity in common with the first as compared with the second. But the other point, the connexion of the school with Capua, demands more attention.

The facts which Mgr. Batiffol gives are these. He knows of six dated manuscripts of known provenance which belong to this school of calligraphy. Without repeating the description which he gives of each manuscript, it will be sufficient to say that these, arranged chronologically, are :-

I. Crypt. B a xx, A.D. 965 , written by Nilus.

2. Crypt. B a iv, between 970 and 991 , written by Luke of Vallelucio, formerly of St. Zacharias on Mount Mercury. This MS is reproduced in Pal. Soc. II 104, but the dating is erroneous and should be as I have given it here ${ }^{2}$.

3. Vat. $213^{8}$, A.D. 991 , written by Kyriakos of Capua.

4. Vat. 2020, A.D. 993, written by Kyriakos of Capua.

5. Laurent. xi 9, A.D. 102 I, written by Luke of the monastery of S. John ( $?$ the Reaper, at Stilo).

1 This was, I believe, first noted by the late Abbe Martin in his 'Quatre MSS importants des Evangiles,' a treatise on the Ferrar group.

${ }^{2}$ For the full details see p. 537 inf. 
6. Vat. 1650 , A.D. 1037, written by Theodore the Sicilian at Reggio.

Mgr. Batiffol has been struck by the fact that of the four older MSS the two Capuan MSS are the ones which have the palaeographical features alluded to previously most clearly marked, and therefore he thinks that the writing is that of a primarily Capuan school.

But, surely, far more important are the facts that the earliest MS was written by Nilus in 965 (that is to say, while he was at S. Adrian's at Rossano); that the second was written by a monk who lived in the monastery which the Abbot of Monte Cassino gave to Nilus, and who had come from the community on Mount Mercury of which Nilus had been one of the chief ornaments; and that the Capuan MSS were written just after the time when Pandolfus had welcomed Nilus, obtained for him the monastery of Vallelucio, and even wished to make him Bishop of Capua.

The life of Nilus, therefore, seems to give the key to the history of these MSS, and they may be considered to have a considerable claim to be regarded as a monument to his practice and teaching of calligraphy, rather than simply as specimens of a school which took its rise at Capua. Nilus, not Capua, is the important fact.

Mgr. Batiffol, however, also quotes three other MSS :-

1. Vat. 1673, which is not dated, but contains a note by the

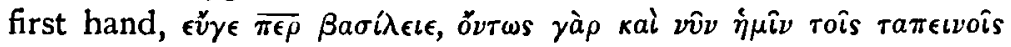

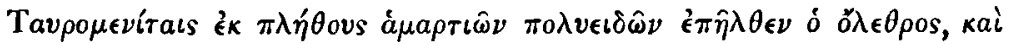
Sixalws.

This, he thinks, refers to the capture of Taormina in 902 .

2. Vat. reg. Gr. 75 , copied by Simeon at Malvito (to the north of the Sila). It mentions in a note by a contemporary hand the expedition of Otto in 982 .

3. Vat. 1633 , undated, but which, from a partly legible note, seems to have come from Bisignano, near Rossano.

There is nothing in the last two to conflict with the theory advanced, but the first requires consideration.

If it is exactly as Mgr. Batiffol thinks it shows that this school of calligraphy is earlier than Nilus; but (I) he says himself that the palaeographical appearances are less marked in this MS. (2) It seems to be doubtful whether the disaster referred to is the 
capture of Taormina, and, even supposing that it is, whether the MS was written immediately afterwards. Therefore I think that this MS does not overthrow the theory advanced, although it would be desirable to examine it more closely.

It is possible that it may prove that Nilus only developed a style of calligraphy which had already been begun, as, from what Mgr. Batiffol says, the general features of the school are much less marked in the Taormina MS than they are in the other MSS.

There is also another type of manuscript which may be traced to the school of Nilus, the tachygraphical MSS of what has been called the Grotta Ferrata school. These MSS are discussed in Mr. T. W. Allen's Notes on Abbreviations in Greek Manuscripts. Any long discussion of this very technical subject would be out of place. I would only suggest that unintentionally Mr. Allen has given a rather exaggerated idea of the closeness of the connexion of this school of writing with Grotta Ferrata.

The chief MSS which can be dated are:-

(I) Crypt. B a xix (vide supra, p. 521), A.D. $9^{6} 5$.

(2) B. M. Addit. I 8,23I (A.D. 972).

(3) Crypt. B a I (A.D. y86).

(4) Crypt. B a iv (before A.D. 992).

All these were written before the convent at Grotta Ferrata was founded ${ }^{2}$. The writer of (2) is unknown. (3) was written by Paul, afterwards Abbot of Grotta Ferrata, another fragment of whose writing was found by Mr. Allen in the Vallicelliana (Cod. Lat. D 43); and the tachygraphical part of ( $I$ ) is not (according to Rocchi) in the same hand as the rest of the MS, but is in that of the above-named Paul.

Although, therefore, the tachygraphical forms may have flourished at Grotta Ferrata, they did not originate there, but were brought from the South by Nilus and his friends, especially Paul.

The conclusion then that has been reached is that the development of the scriptoria in Basilian monasteries of Italy seems to be traceable to the practice and teaching of Nilus, who, probably

1 The present library at Grotta Ferrata is really a collection made by Menniti, and probably contains very few really Grotta Ferrata MSS. To this point I shall refer at a later stage. 
influenced by the Lombardic school of Latin MSS, either founded, or at least developed, a special school of calligraphy and tachygraphy, which he took with him as he gradually went further north.

In this way the Greek monks spread over South Italy. Unless all the arguments here advanced are wrong their history is that of a gradual progress towards the north, which started from very slight beginnings, and by degrees covered with monasteries the land which the Latin monks had left in the days of Gregory the Great. The question naturally suggests itself why these Greek monks held their own, in spite of the attacks of Saracens and other foes, although the Latins had gone at the first blow ?

The reason seems to be partly that their lack of organization helped them. They lived, at least at first, in the deserts and among the rocks, and could easily elude their enemies. Their monastery was, for them, simply the spot where they were staying, and it did not connote the fixed building and elaborate organization that the Latin monks required. In this respect the Greeks offer a striking parallel to the history of the Celtic Church in England, which inhabited and evangelized the north, when the Roman missionaries found it impossible to do anything. The Roman organization and its tendency to live in the centres of population and govern the people, cannot but command respect and admiration, but under certain conditions it was not so effective as a less organized church, which, living away from the towns, appealed to the imagination and conscience by example from a distance rather than by actual teaching, and was protected in times of trouble by its remoteness from the centres of life.

This is partly the explanation of the success of the Greek monks. But it is impossible to read the lives of the Saints, especially that of Nilus, and not be struck by the beauty of their characters. They were superstitious, but it was an age of superstition ; and the important thing which impressed their generation was that they were poor without being either lazy or beggars. In some respects we have improved upon their Christianity, but there are not many stories which breathe a nobler spirit than that of the last meeting between Otto and Nilus ${ }^{1}$. Nilus had

$$
\text { I P. G. } 120, \text { P. } 153 \mathrm{~B} \text {. }
$$


rebuked both the Emperor and the Pope for their cruelty to Philagathus, but as his words were of no effect, he retired to Serperi. After a time the Emperor, who had been stricken with penitence, came to see him. He offered him many things, which the Saint refused, and at last he said, 'Ask what you will, and I will give it you.' The old man laid his hand on the Emperor's shoulder and said, 'I ask nothing of you save the salvation of your own soul. For, Emperor though you be, you are the Subject of death, and shall one day give an account of all your deeds, whether they be good or whether they be evil.' The man who could, under such circumstances, thus speak, deserves the title of saint by some better canonization than that of the mediaeval Papacy, and we cannot wonder that he was famous, and successful in spreading the monastic order which he adorned.

\section{THE FOUNDATION AND SUBSEQUENT HISTORY OF THE MONASTERIES MENTIONED IN THE LIVES OF THE SOUTH ITALIAN SAINTS.}

It is not always easy to fix the exact place in which the early monasteries were founded, and there is a lamentable lack of evidence as to their subsequent history. Possibly more may be found in the Vatican library and archives, especially in Cod. Vat. Lat. $820 \mathrm{I}$, the cartularium of S. Salvator of Messina, and in the 'dossier Basiliani' in the Vatican, a collection of documents from various sources. Both of these will certainly repay investigation, and probably lead to the discovery of more facts ; but it is improbable that much of any fresh material thus obtained will relate to the Pre-Norman monasteries.

I have brought together in this section all that $I$ can find in the $A . S S$. about the early foundations; it would perhaps have been possible to do this in a more connected form, but I think that the superior clearness obtained by keeping each convent separate is an adequate equivalent for the abruptness, and for the small amount of repetition, which the plan has involved.

(i) Salinae. The position of this place has been disputed. The Bollandists and Gaetani ${ }^{1}$ think that it was identical with Aulinae, which, as will be shown, was near Palmi and Seminara

$$
\text { 'A. SS. Aug. iii p. } 497 \text { A. }
$$


to the north of Reggio. Their reasons are that the author of the life speaks sometimes of Salinae, sometimes of Aulinae, and that when, after the death of Elias Junior, Daniel asks Elias Spelaeotes to come and live with him, in accordance with the dying wish of the first-named, it is to Salinae that the Speleote goes, although it is plain from the earlier life that Elias Junior had been living at Aulinae just before his death, and that he was buried there. Therefore they argue Salinae and Aulinae are identical. There would be considerable force in this argument if Salinae were not a well-known place. But it can be found marked on the Italian survey maps close to Capo del Armi (Leucopetra), and Amari has accepted this identification unhesitatingly. It may, however, be well to test this suggested position, and to see if it be possible to explain by it the localities which are mentioned in connexion with Salinae. The passages in the life of Elias which throw light on this point are :-

(I) The description ${ }^{1}$ of Elias's and Daniel's departure from Salinae for Rome: 'Cum ei necesse esset ad Pentadactyli agrum ire ac stagnum quod ibi esset una cum Daniele pervaderet... S. Pantaleonis oratorium ingressus ... ad gallicinium Romam iter tetendit.' Pentadattilo is marked on the map immediately south of Saline. The stagnum does not at present exist, but it is represented by the name Lacco ( $\lambda$ ákкos = a pond), which is still given to part of the neighbourhood between Saline and Pentadattilo. The oratory of S. Pantaleone is represented by a hamlet which bears that name between Pentadattilo and Reggio. Minasi has suggested that it was once a monastery, and he translates oratorium as monasterio. Surely this is unwarranted; the Greek must have been $\pi \rho \sigma \sigma \epsilon u \chi \eta^{\prime}$, and need not mean more than a wayside shrine. I cannot trace Minasi's statement that the monastery of Pantaleo passed into the control of the cathedral of Bova. He gives no authority, and I can find none in Agresta, Rodota, or any lists of visitations.

Is ad gallicinium a note of time or of place? I think it is probably the former, as the Bollandists give no note on the subject, and do not print it with an initial capital. I therefore suggest that they found gallicinium in their old Latin version and $a \lambda \in \kappa$ เopoфwviav in their Greek (v. Ducange, s.v. galliciniale).

1 A.SS. Aug. iii p. 497 A $(=D)-$. 
Minasi, however, has not noticed this possibility, and thinks that they put no note because they did not understand the word (whereas the Bollandists constantly add notes to explain that they do not know the meaning of phrases), and points out that there is still a district north of Pantaleone called Galliciano. This is a very interesting suggestion, but I can hardly believe that if the Bollandists had had yaגiıivıov in their Greek text, they would have simply transliterated it without comment.

(2) The description of Daniel's journey ${ }^{1}$ home from Salonica with the dead body of his master:...' ad Ruscianorum (Rossano) oppidum appellitur, ac post equo vectus in Besianum castrum venit... ad Salinas proficiscitur sancti translationem fratribus significaturus ... omnes tamen libenti alacrique animo in Taurianum ... illi obviam processere.'

At first sight the mention of Tauriana seems to imply that Salinae was close to that city. But it is certain that Elias was buried at Aulinae. If, therefore, Aulinae and Salinae are the same place or close together the narrative has no sense, for it implies that the monks on hearing that their founder's corpse was being brought to Aulinae for burial straightway went off to Tauriana, a town which by that route it would never go near. But the whole story becomes simple if it is supposed that Daniel went first to Salinae to announce that he was taking the body to Aulinae round the Aspromonte by the road which runs along the coast through Tauriana-the only practical course, for it would have been a very serious task to have taken it over the top of the mountain. It remains to identify Besianum castrum. The Bollandists cannot; but Minasi suggests that it is a mistake for Mesianum castrum, an old tower on C. Mileto. This fits in with the rest of the narrative and is very probable, as in Greek minuscule MSS $\mu$ and $\beta$ (written $u$ ) are constantly confused.

As the result of this investigation it is clear that the evidence is in favour of identifying the old Salinae with the modern Saline. The convent there is interesting, because it is the first of the Basilian monasteries of whose foundation we hear the story in a trustworthy narrative, but it cannot claim a long or famous history. Elias and Daniel left ${ }^{2}$ it in 888 and took refuge at Patras, on account of the attack which the Saracens were making

${ }^{1}$ A.SS. Aug. iii p 507 B-c.

VOL. IV.
'A. SS. tom. cit. p. 498 A.

$\mathbf{M} \mathrm{m}$ 
on Reggio. Probably they joined Elias Spelaeotes and Arsenius in this flight, but unlike the two last, who remained at Patras for eight years, Elias Junior and Daniel soon returned. First of all they went back to Salinae ${ }^{1}$, but soon afterwards they sought a quieter life in the hills of 'Mesobianum'2, a district which no one seems to be able to identify certainly. It may mean generally the Aspromonte; but as it is mentioned in the life of the Speleote in connexion with $\mathrm{S}$. Christina, a village east of Seminara, it is perhaps the northern side of the mountain. It was probably at this period that Elias founded the monastery of Aulinae, for only one more visit to Salinae is recorded and the rest of the story is concerned with Aulinae. Only once more can I find any trace of the monastery of Salinae. This is in the life of Elias Spelaeotes ${ }^{3}$, where it is recorded that Daniel went to live at Salinae after the death of Elias Junior, and in obedience to a suggestion which Elias Junior had once made, invited the Speleote to come and live with him. Elias came, and there is an amusing account of the way in which Daniel kept him waiting outside the convent in order to test his perseverance; and, on the other hand, of the way in which Elias rebuked Daniel for his laziness in wishing to go to bed instead of reciting the Psalter.

But Elias did not stay there long, and retired to a cave on the hills, probably near Melicucca 4.

Nothing more is known of Salinae, nor is there anything to show whether Daniel had many followers or lived almost alone.

If we may judge from the absence of all further information, we may guess that Salinae was destroyed by some invasion of the Saracens before the end of the ninth century, or possibly at the beginning of the tenth, and that it was never rebuilt.

(ii) Aulinae. Aulinae was the second monastery founded ${ }^{5}$ by Elias Junior. The time in his life when he founded it is open to doubt. As was said above, Elias Junior and Daniel in 888 retired from Salinae to Patras, fearing the advancing strength of the Saracens, but after a short time returned to Salinae. The account of what he did next is rather difficult to follow, and the Bollandists say that the Greek MS is deficient at this point;

1 A. SS Aug ini p. 498 в.

$A . S S$ Sept. iii p. 862 r.

2 A. SS. tom. cit. p. 498 B.

$4 A$. SS. tom. cit. p. 863 C.

- A. SS. Aug. iil p. 498 A. 
there is, however, no real reason for doubting the substantial accuracy of the old Latin version which was made before the MS was mutilated. According to this he was much disturbed by constant visitors who were attracted by his fame, and retired ${ }^{1}$ 'pacatiorem vitam exacturus'-to the 'Mesobian ' hills. This probably means the foundation of Aulinae, though the fact is not expressly stated. He did not stay there long, as he was warned of a new attack which was soon to be made on Reggio, and consequently moved back to Salinae in order to be in a spot more convenient for preaching to the inhabitants of Reggio and warning them of their danger. "The disaster referred to would seem to be the fall of Reggio in 900-I.

After this, perhaps because of this, Elias again retired to Aulinae and does not seem to have ever returned to Salinae. With the exception of a visit to Amalfi, apparently just before the fall of Taormina in 902, he remained at Aulinae until he was summoned to Constantinople by Leo VI. He died, on his journey thither, at Salonica in 903, and his body was brought back to Aulinae by Daniel.

The situation of Aulinae is fixed by tradition as on the western extremity of the mountain which overlooks Palmi and which is pointed out to the traveller as the Monte Elia. It is said that there are some ruins there: this may be true, but it is very improbable that the original monastery of Elias ever was built so strongly as to have survived to this day. Confirmation of this site may be found in the reference which is made in the Life of Elias Junior to Christina, a town which still appears on the map. We are told" that 'ea itaque clade impendente, Elias ac Daniel, viri plane admiratione digni, Christique cultores egregii in Sanctae Christinae castrum proficiscuntur. Ibi dum de paenitentia... verba faciunt, auditores . . . incolumes servantur ... His gestis in monasterium (i. e. Aulinas) revertuntur.'

This suggests that Christina was near Aulinae, but does not define its exact position. Similarly, in the life of S. Philaretus we read that Philaretus ${ }^{3}$, going from Reggio, 'inde in Aulinas... adventavit ... ibi in quodam oppidulo Sinopoli ... suum domicilium collocarunt.'

I A. SS. Aug iii $49^{8} \mathbf{B}$. 3. SS. Apr. i p. 609 B.

2 A. SS. tom. cit. p. 498 F.

M $\mathrm{m} 2$ 
After Elias Junior's death we are told in his Life that Leo VI ${ }^{1}$ endowed his monastery, 'census et praedia . . . libentissime attribuit.' This is a statement which cannot be checked. To some extent it depends on whether we believe the story that Leo sent for Elias. I confess that I should hesitate to attach much weight to it, not because there is no documentary evidence, but because it is a story which was so likely to be invented. The monastery did obtain census and praedia, and no title could be more satisfactory than an imperial gift, therefore the story would naturally arise. I do not see how it is possible to decide either way.

It is of the flourishing and rich monastery endowed with census and praedia that we obtain a picture in the next document, nearly $15^{\circ}$ years later, the Life of S. Philaretus. By this time the monastery was known as that of S. Elias and the body of the saint was its most precious relic. Philaretus was a Sicilian by birth, who was taken in his childhood from his home in Traina to Reggio and thence to Mount Aulinas, where he lived in the little town of Sinopoli. With the leave of his parents Philaretus entered the monastery and remained there all his life, attaining a great reputation for sanctity. It is important to note the conclusion of the Life of this saint, for its bearing on the further history of the monastery. 'Ut te,' it runs ${ }^{2}$, 'beatissimum et fortunatissimum inter omnia monasterium appellem, quam longa de encomiis contexi potest oratio quoniam geminos in te continens soles divinis sane thesauris opulentum enitescis.' It is obvious from the whole tenor of the Life that the author is living in the same monastery in which S. Philaretus and Elias had lived, i.e. the one which the Life of Elias calls Aulinae; and this encomium shows that already S. Philaretus had been placed on a level with Elias. We should therefore naturally expect to find that S. Philaretus soon came into the title of the monastery. Now in $13^{29}$ we find in the Cartularium of the monastery of S. Salvator of Messina (Cod. Vat. Lat. 820I) a reference to the monastery of SS. Elias and Philaretus, in the following document :-

'Anno 13293 Octobris XII indictionis apud monasterium Sancti Eliae et Philareti pertinentiarum (?) terrae Seminariae

1 A. SS. Aug. iii p. 507 D.

2 A. SS. Apr. i p. $618 \mathrm{~d}$. 
Joannis Papae XXII anno XIV F. Neophitus humilis abbas dicti monasterii propter gravem infirmitatem et longam, et propter senectutem nimiam impotens ad dictam curam exercendam renunciat dictum abbatiatum apud Reverendum in Christo Patrem et Dominum Dom Ninphum Archimandritam Maioris Monasterii S. Salvatoris de Lingua Fari Messanae, et ob ejus absentiam in manu venerabilis F. Neophiti Abbatis S. Pancratii de Scilla generalis procuratoris et oeconomi dicti Archimandritae.' Either this is a reference to the old monastery on Aulinas, or to a colony of it. I see no reason for thinking that it must be the latter, and regard the document as a sign that the monastery was one of those in Calabria which in the great Norman reorganization were placed under the monastery of S. Salvator.

Another hundred and fifty years elapse before we find any further reference to the monastery of SS. Elias and Philaretus.

It appears in the Liber Taxarum of 1482, preserved in Vat. Lat. 9289 , and printed by Mgr. Batiffol ${ }^{1}$, as paying to the Camera Apostolica a yearly tribute of seventy florins. This shows that it was still maintaining a fair position among the smaller monasteries, though of course it could not compare with the great foundation of S. Maria of Grotta Ferrata, which paid 900 florins $^{2}$; but like all the Basilian monasteries it was falling upon evil days, and when in $155 \mathrm{I}$ it was visited by Marcellus Terracina he only found five monks ${ }^{3}$. The last record of all speaks for itself: it is a bill sent in by Giovanni Santamaura a scribe of Cyprus, for making manuscripts for the use of the church. When monks have so far sunk as to employ a secular scribe to write their manuscripts, they can scarcely claim our sympathy in their decadence and speedy extinction.

In this short account of the few traces which seem to remain of the monastery which Elias Junior founded on Mount Aulinas, I have assumed that the identification with the monastery of SS. Elias and Philaretus is correct. If so it may be noted that it enables us to fix its exact situation, as Terracina says ${ }^{6}$ that it

1 L'Abbaye de Rossano, p. 108.

2 L'Abbaye de Rossaro, loc. cit.

- L'Abbaye de Rossano, p. Iog f. Cf. Montfaucon, Pal. Gr. p. 112, and Cod. Paris. Lat. $13,08 \mathrm{I}$, fol. I-6.

- L'Abbaye de Rossano, p. 124 . There are several MSS by this scribe in Paris and Rome. Possibly this bill may help to trace their bistory.

s'Abbaye de Rossano, p. 110. 
is two miles from Seminara, and I believe that ruins are still to be found on that spot. If, however, the identification be not correct, we must suppose with Minasi that at some period after the death of Philaretus the monks left Aulinae and went to the new monastery. He thinks that the original monastery was nearer to Palmi. I fail to see that any passages in the lives of Elias or Philaretus necessarily imply the one situation rather than the other, and the mere presence of a few stones on the Palmi site proves little. The point must be left open, but it could probably be solved if some scholar would pay a visit to the neighbourhood and examine all the ruins which he can find on both sites.

(iii) Armo. The Armo of to-day is a little village, about nine miles from Reggio and less than three from an old castle called S. Agatha, and Elias and Arsenius about 886 took up their abode near a church called S. Eustrazius, close to Armo ${ }^{1}$. I do not see any reason for thinking that this was then a monastery; but there seems to have been one (either here or in the immediate neighbourhood) a little later, when Elias had gone to Melicuccà, as we are told that a certain monk named Luke ${ }^{2}$ was sent by Elias to the monastery near the castle of S. Agatha. I should conjecture that the stream of monks which begins to become noticeable in the time of Elias Junior, and drove him to leave Salinae in order to lead a quieter life, had taken possession of the old hermitage of Elias and Arsenius, and turned it into a monastery.

Minasi ${ }^{3}$ suggests that this may have been replaced at a later time by the monastery in that locality of S. Maria Trapezomata, which was built by Count Roger of Sicily.

(iv) Melicucca. Melicuccd is the great monastery founded in a cave by Elias Spelaeotes. It illustrates the gradual development of monastic life from a collection of hermits living near each other, and joining in a common worship, to a true coenobium; and the record is specially valuable as it is no doubt typical of what happened elsewhere, although we have not always documentary evidence of the change.

In 888 Elias went from his hermitage at Armo, near Reggio,
1 A.SS. Sept. iii p. 854 F.
2 A. SS. tom. cit. p. 867 B.
Lo Speleota, p. 168. 
to Patras ${ }^{1}$, probably going with Elias Junior and Daniel, and certainly with the old hermit Arsenius, whom he had joined. At Patras he stayed eight years, and then Arsenius and he returned $^{2}$ to Armo. Arsenius died about 900-2, and after the death of Elias Junior, Elias Spelaeotes went to live for a short time with Daniel at Salinae. He did not stay here long, but retired with two other monks, Cosmas and Vitalis, to a cave ${ }^{3}$ in the 'Mesobian' mountains, at Melicuccà. There is no difficulty about identifying the situation of this monastery, as the tradition is firm and the ruins are indisputable. It is about three miles to the east of Seminara, and therefore not far from the monastery of Elias Junior on Mount Aulinae. Cosmas and Vitalis did not stay long with Elias, as they wished for a more secluded life and were disturbed by the number of monks who came to live near Elias and formed a Laura. After a time Elias found the original cave was too small, and the monks moved to a larger cave in the immediate neighbourhood. This was improved by the addition of a window, and it was dedicated to S. Peter and S. Paul.

This monastery at Melicuccd remained under the rule of Elias until his death, and seems to have been the training-school for all the most celebrated monks of the district. It produced Lucas of Armento, or Demena 4 , the founder of the Basilian monasteries in the Basilicata; and probably Fantinus, Zacharias, and John of the Mercury monasteries, which will be dealt with later.

There were periods when the monastery, in common with the rest of the district, was threatened by the Saracens, and the monks usually scattered for a time; and in one of these periods Lucas went to the Basilicata, and Fantinus to Salonica. It is a curious fact, which I am unable to explain, that there is no mention of Elias Spelaeotes in the Life of Nilus, who was living in the cave of S. Michael, in the neighbourhood, from about 940-50.

The subsequent history of Melicuccà is doubtful. Minasi 5 repeats a story, which he was told by a priest at Melicucca, that the Byzantine emperors endowed it. It is said that there are documents (? at Melicucca) to support this, but they are not

t A. SS. Sept. iii p. 856 z.

${ }^{2}$ A. SS. tom. cit. p. 860 r.

3 A. SS. tom. cit. p. $86_{5} \mathrm{C}$.

- The meaning of Demena is uncertain. It is thought to be a locality in Sicily.

3 Lo Speleota, p. 236. 


\section{THE JOURNAL OF THEOLOGICAL STUDIES}

published, and the story sounds suspiciously like an echo of the similar one about Aulinae in the Life of Elias Junior.

It is also said that Robert Guiscard in 1062 confirmed the privileges of this monastery; but here again the only evidence is Minasi's account of the statements of the priest of Melicuccà. Other than this I can find no trace of the monastery until its visitation in $155 \mathrm{I}$ by Terracina ${ }^{1}$, who found living in it a solitary monk. This dilapidated and deserted condition accounts for its absence from the Liber Taxarum of $1482^{2}$.

(v) The Monasteries of the Mercurion. In the Life of S. Nilus mention is made of the monasteries of the Mercurion. This has been misunderstood, and taken to imply the existence of some monastery dedicated to S. Mercurius. It is, however, clear from the language of the Life that Mercurion is the name of a district, not of a monastery; for instance we find that he speaks of $\tau \grave{a}$

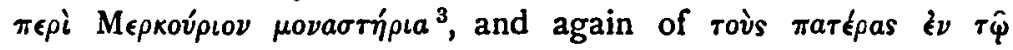
Meprovply *. Later on the writer speaks of at least two monasteries in this district, S. Fantinus ${ }^{5}$ and $S$. John ${ }^{5}$, and perhaps a third, S. Zacharias ${ }^{5}$, should be added. So far as I have been able to find out, these monasteries never afterwards attained to any importance, but there are two mentioned in Terracina's visitation which must be the same foundations. They are near Seminara, and Terracina ${ }^{6}$ says: 'Die 28 Aprilis decessimus a monasterio Sancti Heliae et Sancti Philareti et accessimus ad monasterium $S$. Johannis de Lauro et invenimus ecclesiam quasi speluncam latronum et sine cultu divino. ... Die predicto discessimus a monasterio S. Johannis de Loro et accessimus ad abbatiam S. Phantini de Seminaria ubi invenimus corpus S. Phantini, sed ecclesiam destructam a Mauris.' These sound as if they were the two monasteries mentioned in the Life of S. Nilus, and if so their history must have been the same as that of the neighbouring monastery of SS. Elias and Philaretus, for they appear in the list of Calabrian monasteries which were in the control of S. Salvator of Messina. Probably the Cartularium of S. Salvator (Cod. Vat. Lat. 820I) contains a document bearing on this point.

'L'Abbaye de Rossano, p. I10. (N.B. pro Wiclicona L. Melicuccà).

'L'Abbaye de Rossano, p. Ioy f.

- P. G. 120, p. 33 .

'P. G. 120, p. 21.

- L'Abbaye de Rossano, p. I 10.

3. G. 1 20, pp. 24, 33, and Cod. Crypt. p. 62. 
It will be noticed that this account says nothing of the monastery of S. Zacharias. This silence is probably explained by a

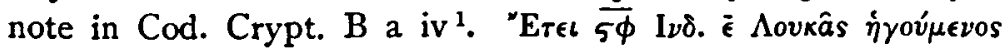

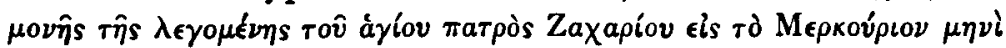

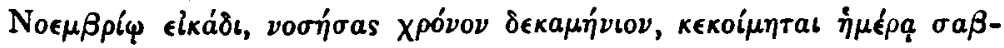

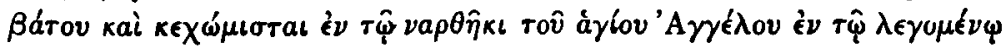

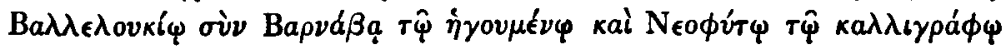

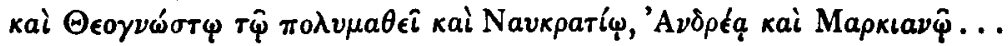

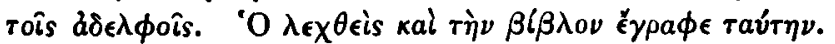

This notice suggests that in the great exodus of 950 the monastery of Zacharias was abandoned, and that Luke the abbot sooner or later joined Nilus.

If then we accept the two little monasteries of Johannes de Lauro and Fantinus as the representatives in later times of the monasteries of the Mercurion, the latter name must be explained as probably due to some memory of a temple of Mercury which used to exist on the hill near Seminara. There is evidence that this district was, and probably is, so called, as is shown by a quotation which Minasi ${ }^{2}$ gives from the Notizie storiche $e$ topographiche intorno Metauria e Tauriana (pp. 99-100). The important part of the reference is the following: "Alla contrada San Filippo, la quale viene attraversata della strada tra Palmi e Gioia, fa continuazione verso sud est, l'altra, detta Sidaro, tutta declive scoscessa in più luoghi è limitata in basso da una vallata poco profonda, che la divide da un' altra contrada chiamata san Mercurio, la quale per buon tratto trovasi dal lato opposto fiancheggiata da un altro avvallamento,' etc.

It is difficult to follow this description, but it seems to point to the district north of Seminara.

(vi) S. Nazarius. When the governor of the province prevented the monks of the community on Mount Mercury from accepting Nilus as a monk, he was sent to the monastery of S. Nazarius, where he was received. Agresta and the Bollandists $^{3}$ say that this monastery is S. Philaretus (Aulinae). This is doubtful, for two reasons :-

(I) Nothing would have been gained by going to Aulinae, which was in the same district.

1 Rocchi, Codices Cryptenses, p. 62. , San Nilo, p. 266.

$P$. G. 120, p. 24 D (quoting the notes of the Bollandists). 
(2) Bartholomew says that on his journey Nilus had the sea on his left hand and the bushes on his right. But the Mercurion was north of Seminara, two miles from which is S. Philaretus, and therefore if Nilus were walking with the sea on his left hand he cannot have been going to S. Philaretus.

It is therefore more in accordance with the narrative to suppose that S. Nazarius was a monastery to the north of the Aspromonte and outside the Byzantine district. Assuming that these events took place about $940-5$, it is difficult to say exactly how far north this would be, but it is probable that the Lombard rule extended down to the north of Calabria, or at all events that the effective Byzantine rule did not extend to the northern limit of Calabria.

On the other hand, I do not feel that these arguments are quite decisive. Agresta says that $\mathrm{S}$. Philaretus was once called S. Nazarius. He gives no evidence, but he was in a far better position to know than is Minasi ${ }^{1}$, who rejects his statement as unfounded. If Agresta should prove to be correct, and no monastery of this name should be found in the north (at present none is known), I should be inclined to argue (I) that the difficulty about the road is not insurmountable, as all travellers know that the winding of a road in a mountainous district sometimes makes them go for a time almost in the exact opposite of their real direction; (2) that the argument about the Byzantine jurisdiction is based on an exaggeration both of the closeness with which the officials would or could watch the district of the Aspromonte, and of the law-abiding character of monks. After all, the situation was a simple and common one; Nilus had deserted his wife ${ }^{2}$, and wished to become a monk. The Byzantine law forbade this, and his wife seems to have invoked its help ; a messenger ${ }^{3}$ was sent to the monasteries on Mount Mercury and threatened the monks. The monks yielded, but Nilus went to another monastery, on the neighbouring hill, Mount Aulinae, which had not been warned. No doubt the government officials might have been more energetic and the monks more law-abiding, but the Aspromonte was a long way off, and unless Nilus's wife was very rich she could do nothing more.

1 San Nalo, p. 286.

2P. G. I 20, p. 21 в f.

3. G. I 20, p. 24 B. 
The whole proceeding was illegal and unjustifiable, but it can hardly be said to be inexplicable.

There is another argument in favour of Agresta's view, though it is not to be pressed, in the fact that, so far as we have seen, there is very little evidence for thinking that the Basilian monasteries had spread beyond the Aspromonte in 940-5; and to suppose, as Minasi does, that there was a monastery of S. Nazarius in the north of Calabria is contrary to all the facts which we know about the spread of Basilian monasticism in South Italy.

Therefore, although admitting that the monastery on Mount Aulinae is not indicated by the narrative, I do not think that Minasi is right in summarily rejecting the statement of Agresta.

(vii) S. Anastasia. According to the Life of Nilus ${ }^{1}$, this nunnery was founded by Euprasios, the Imperial judge in the district, who had placed a monk named Antonius in charge of it. Antonius, on his deathbed, sent for Nilus and asked him to look after it. Nilus found it in a neglected state, and worked hard to reduce it to proper order. I can find no trace of its subsequent history, but Agresta ${ }^{2}$ adds, 'hoggi appellato S. Biase di Valo o come altri vogliano S. Marco.'

(viii) The Convent at Arenario. Nilus is represented ${ }^{3}$ as sending the mother and sister of his companion Stephen to a nunnery in the district called Arenarion. Agresta ${ }^{4}$ identifies it with one near Rossano, once called S. Opoli, and in more recent times Varco del Rinacchio. Minasi ${ }^{5}$ rejects this identification, on the ground that Nilus was, at the time referred to, still in the Mercurion. He thinks therefore that Arenarion means the country near the town Arena, about twenty miles north of the Mercurion. I do not feel convinced that Minasi is justified in this argument. It seems to me that this part of the Life of Nilus deserts the strict chronological order in order to bring together all the stories in which Stephen plays a part. The most convincing proof of this is the mention of Fantinus in the story of the broken saucepan, for we have been already told of Fantinus's departure (to Thessalonica). Minasi also thinks that the ignorance ${ }^{6}$ which the writer expresses as to whether

${ }^{1}$ P. G. 120, P. 85 B.

SP. G. 120, p. $6+$ A.

s S. Nilo, p. 296.
- Vita di S. Bastlio, p. 35 2.

- Vita ds S. Bastlio, p. 351 (? 352).

- P. G. 120, p. 64 A. 
Theodora, the abbess at Arenarion, is the same as a Theodora who knew Nilus as a child, shows that the convent was not near Rossano in which Nilus passed his boyhood. I fail to under. stand this argument. Surely the whole point of the statement is that although circumstances would suggest that the Theodora of Nilus's childhood is the same as the Abbess Theodora, the writer has no certain knowledge on the subject. So far as it goes this seems to be an argument in favour of some monastery near Rossano, but it is not a point on which stress could be laid.

The situation of this convent is therefore doubtful. In any case there is nothing known of its further history. Agresta merely mentions that its ruins could be seen in his day, and it is not mentioned in the census list of the Rossano diocese of $1437^{1}$.

(ix) S. Adrian of Rossano. Nilus left the district of the Mercurion when the Saracens began to render it uninhabitable or dangerous, and retired north to his native district, Rossano. Probably there were no monasteries here at this time, but there was at some distance from the city a shrine of S. Adrian. Here Nilus, with Stephen and George as his companions, established himself. It appears from the account in his Life that, although Nilus was the most prominent figure and the real chief in this monastery, Proclus ${ }^{2}$ was the titular abbot. They stayed at S. Adrian's until Nilus, fearing an attack by the Saracens (this was just after Kasem's invasion, and so probably about 976), decided to go further north, and departed to Monte Cassino.

The remaining history of $\mathrm{S}$. Adrian is obscure. It appears from the census list ${ }^{3}$ of the diocese of Rossano, which is bound up with a Graeco-Latin Psalter in Cod. Barberin. $v$ 17, that in the fourteenth century it was the seat of an archimandrite, and paid three ounces of gold annually to the bishop of the diocese. But in the last years of the fifteenth century it suffered many misfortunes, owing to the grasping and cruel conduct of the monks towards the Albanians ", who, taking refuge from the Ottoman persecution in the dependent houses of S. George and 'della Macchia,' were treated by the officers of S. Adrian with extra-

1 Cod. Barber. v 37, f. 8, printed in L'Abbaye de Rossano, p. II f.

2 p. 4o. Extract from $A . S S$.

- Rodota, II Ruto Greco, ii p. 193 ff.

' L'Abbaye de Rossano, p. $117 \mathrm{f}$. 
ordinary severity. 'Finally,' says Rodota, 'per far respirare i sudditi dalle insoffribili oppressioni,' the Pope placed S. Adrian's in ' commenda.'

In 1743 Pope Benedict XIV restored to it its income, and gave it civil jurisdiction over the territory of $S$. Demetrius and the two houses of S. George and 'della Macchia,' on condition that it paid the abbot in 'commenda' I 500 scudi. This was ratified by the Bull of Sept. 22, 1743 .

But before thirty years were past, the monks of S. Adrian's were again in trouble. They were convicted by Cardinal Giuseppe Spinella of trying to obtain by false pretences the control of the Benedictine house of S. Maria di Giosafat. The result, in Rodota's words', was that: 'I Basiliani, combattuti per qualche tempo da contrarii affetti, agitati da diverse passioni, considerando l'incertezza dell' esito della lite, sono venuti all' amichevole e perpetua composizione di quelle ritenere con aumentare altri scudi .500 all' annuo precedente canone, che forma l'intera somma di scudi 2000 , da pagarsi liberamente in Roma ai futuri commendatarii.'

This arrangement was ratified by the Bull of March 30, 1759, of Clement III. It is perhaps not without its bearing on this incident that probably Cardinal Spinelli was himself the commendatory who would receive this increased income, though Rodota's words are a little ambiguous on this point.

Minasi has so misread the story as to represent the whole matter as a triumph for the monks of S. Adrian's, who received both the abbey of S. Mary's and also an increased income of 2,000 ducats.

In $1794^{2}$ the monastery was suppressed in order to supply funds for the Greek College in Rome.

(x) Vallelucio. This monastery was a dependency of Monte Cassino, in which Nilus and his friends stayed for some years. It cannot be reckoned as a Basilian monastery.

(xi) Serperi. After leaving Vallelucio, Nilus established himself at Serperi near Gaeta. He stayed here until he and the monks who were with him moved to Tusculum. Apparently it was not afterwards used as a monastery. 
(xii) The Monastery at Noia ${ }^{1}, S$. Fulian's of Armentum, Rapora. Of these and the other monasteries mentioned in the Lives of Lucas and Vitalis I can find no trace at a later period. The whole monastic life of Greeks in the Basilicata seems to be gathered up in the history of the monastery of Elias of Carbo, and its dependencies, which will be dealt with later.

(xiii) S. Mary's at Grotta Ferrata. This convent does not come within the scope of this essay. Its history can be found in Dom Rocchi's books La Badia di Grotta Ferrata and De Coenobio Cryptoferratensi.

This list of monasteries is not necessarily a complete record of all the monasteries which were founded during the early period. It is only intended to be an account of the foundations which are mentioned in the Lives of the local saints; there may have been others. At the same time, as I have already stated, the impression made on my own mind by reading these Lives is that there were not many others until a later date.

K. LAKE.

1 Agresta mentions the existence of a monastery of S. Peter at Noia, but gives no details.

(To be continued.) 